\title{
Analgesic, anti-inflammatory and antipyretic activities of ethanol extract of Annona senegalensis leaves in experimental animal models
}

\author{
Anthony U. Megwas ${ }^{1}$, Godwin C. Akuodor ${ }^{2 *}$, Leo C. Chukwu ${ }^{3}$, Daniel O. Aja \\ Edmund M. Okorie ${ }^{1}$, Elochukwu C. Ogbuagu ${ }^{5}$, Desmond O. Eke ${ }^{4}$, Anuli N. Chukkwumobi ${ }^{6}$
}

${ }^{1}$ Department of Optometry, School of Health Technology, Federal University of Technology, Owerri, Nigeria ${ }^{2}$ Department of Pharmacology and Therapeutics, College of Health Sciences, Faculty of Medicine, Nnamdi Azikiwe University, Nnewi Campus, Nigeria

${ }^{3}$ College of Medicine, Chukwuemeka Odumegwu Ojukwu University, Amaku, Awka, Nigeria

${ }^{4}$ Department of Pharmacology and Therapeutics, Faculty of Medicine, Ebonyi State University, Abakaliki, Nigeria ${ }^{5}$ Department of Pharmacology and Therapeutics, College of Medicine, University of Nigeria, Enugu Campus, Nigeria ${ }^{6}$ Department of Internal Medicine, Chukwuemeka Odumegwu Ojukwu University Teaching Hospital, Awka, Nigeria

Received: 20 July 2020

Accepted: 31 August 2020

\section{*Correspondence:}

Dr. Godwin C. Akuodor,

Email: goddyakuodor@yahoo.com

Copyright: $\odot$ the author(s), publisher and licensee Medip Academy. This is an open-access article distributed under the terms of the Creative Commons Attribution Non-Commercial License, which permits unrestricted non-commercial use, distribution, and reproduction in any medium, provided the original work is properly cited.

\begin{abstract}
Background: This study was carried out to establish the analgesic, anti-inflammatory and antipyretic effects of the ethanol extract of Anonna senegalensis leaves in experimental animals.

Methods: The analgesic activity was measured using the abdominal constriction and tail flick tests. The antiinflammatory activity was performed using xylene and egg-albumen paw induced tests, while the antipyretic activity was measured using brewer's yeast and 2, 4 dinitrophenol induced pyrexia tests, respectively.

Results: The leaf extract at all doses used exhibited significant $(\mathrm{p}<0.05)$ analgesic, anti-inflammatory and antipyretic activities.

Conclusions: Results show that ethanol leaf extract of Anonna senegalensis possess therapeutic potential against pains and feverish conditions, supporting the claims of its this plant as remedy for similar ailments.
\end{abstract}

Keywords: Anonna senegalensis, Analgesic, Anti-inflammatory, Antipyretic

\section{INTRODUCTION}

Herbs have proven to be of high importance for prevention and treatment of diseases, and of high value to immunological provocation against much pathologic conditions. ${ }^{1}$ Almost all plant extracts are virtually used for treatment and prevention of diseases. Many of these plant extracts boost humoral cell mediating immunity against bacteria, virus, fungi, protozoa, cancer and even haematological cells and parameters. ${ }^{2,3}$ Annona senegalensis pers. (Annonaceae), commonly known as
Africa custard - apple, and wild sour sop, is a specie of flowering plant in the custard apple family. ${ }^{4}$ The plant is a perennial shrub which is widely grown in Nigeria. A. senegalensis is locally known as "Gwander daji" in Housa, "Abo" in Yoruba, "Uburu ocha" in Igbo, and "Ikpoko" among the Idoma speaking people in the middle Belt region of Nigeria. ${ }^{5}$ The leaves, flowers and fruits are edible, and are used by local population in treating many health conditions, ranging from dizziness and indigestion, to chest pain, colds and venereal diseases. The bark can be processed to produce yellow- brown dye used locally 
as insecticide and pesticide. ${ }^{6}$ In Nigeria, particularly, the roots are used to treat pains. ${ }^{7}$ The leaves and stem are used for the treatment of intestinal problems. ${ }^{8,9}$ Cancer treatment, diarrhoeal and dysentery, Antimicrobial and anticonvulsant, Trypanasomiasis., ${ }^{4,5,10-12}$ Other applications of the leaf extract include neurological disorder and testicular function indices. ${ }^{13,14}$ However, our interest in this plant was justified by its important medicinal value in the treatment of pains and feverish conditions.

Therefore, the objective of this study was to evaluate the analgesic, anti-inflammatory and antipyretic properties of the ethanol extract of $A$. senegalensis leaves in experimental animals.

\section{METHODS}

\section{Plant collection and identification}

Fresh leaves of Annona senegalensis were collected from Suleja, Niger State, Nigeria. The plant was identified by a taxonomist in the department of Medicinal Plant Research and Traditional Medicine, National Institute for Pharmaceutical Research and Development (NIPRD), Abuja, Nigeria.

\section{Extraction procedure}

The leaves were washed, shade dried at room temperature in the Department of Optometry, School of Health Technology, Federal University of Technology, Owerri and subjected to size reduction to a coarse powder by using mortar and pestle. Four-hundred grams (400 g) of the powder was macerated in 2.51 of ethanol for 24 hours with frequent agitation until the soluble matter has dissolved. The mixture was strained, the marc pressed and the filtrate concentrated to dryness by gentle heating over a water bath set at low temperature $\left(40^{\circ} \mathrm{C}\right)$ to obtain a semi solid brownish extract. The extract was stored at $4^{\circ} \mathrm{C}$ in a refrigerator till when needed for the assay.

\section{Experimental animals}

Adult Wistar rats (200-250 g) and albino mice (20-25 g) of either sex were used in this study. The animals were sourced and maintained at the Animal house of Federal University of Technology, Owerri, Imo State. The animals were acclimatized for 2 weeks prior to the tests. They were fed with standard diet and had access to clean water ad libitum. They were maintained under standard conditions of humidity, temperature and 12 hours light and 12 hours darkness cycle. The study protocol was carried out as per the rules and regulations of the Institutional Animal Ethical Committee, School of Health Technology, Federal University Technology, Owerri (FUTO/SOHT/REC/02/0101) as well as the international guidelines on the Use and Handling of Experimental Animals. ${ }^{15}$

\section{Acute toxicity test}

Oral acute toxicity test was performed using the organization of economic cooperation and development (OECD) guideline for testing of chemicals $401 .{ }^{16}$ Male and female rats weighing 180-200 $\mathrm{g}$ were used for this study, and were conducted in two phases. Three groups of 3 rats (male separated from female) in each cage were administered 100, 600 and $1000 \mathrm{mg} / \mathrm{kg}$ of the Anonna senegalensis leaf extract orally. The rats were observed for signs of toxicity and mortality for $24 \mathrm{hrs}$ with special attention given to the first $4 \mathrm{hrs}$. This was followed by administration of the extract (2000, 3000 and 5000 $\mathrm{mg} / \mathrm{kg}$ ) to the next three groups of 1 rat and equally observed as earlier stated, and daily for 7 days for any signs of toxicity which include salivation, paw-licking, writhing, change in body weight and mortality. The number of deaths in each group was recorded and the final LD50 values were calculated.

\section{Phytochemical analysis}

The ethanol extract of Anonna senegalensis leaf was screened for the presence of active constituents using the methods described by slight modifications. ${ }^{17,18}$

\section{Analgesic activity}

\section{Acetic acid-induced writhing test}

This test was done using the method described by Akuodor et al adult albino mice of both sexes, weighing between 20-25g were used for the study. ${ }^{19}$ The animals were divided into five groups of 6 each and pre-treated as follows. Group 1, which serves as control, received 20 $\mathrm{ml} / \mathrm{kg}$ of normal saline. Group 2, 3 and 4 received 100 , 200 and $400 \mathrm{mg} / \mathrm{kg}$ of A. Senegalensis extract, respectively. Group 5 received acetylsalicylic acid (ASA) $150 \mathrm{mg} / \mathrm{kg}$. All the treatments were administered orally. Thirty minutes after drug administration, each mouse was intraperitoneally injected $20 \mathrm{ml} / \mathrm{kg} \quad 0.7 \%$ solution of acetic acid in distilled water to create pain sensation. Each mouse was then placed in transparent Perspex observation box, and the number of abdominal constrictions for each mouse was counted for $30 \mathrm{~min}$, commencing 5 min after the administration of acetic acid.

\section{Tail immersion test}

This test was carried out using the method described by Akuodor et al with slight modification. Thirty mice were randomized into five groups of 6 in each cage. ${ }^{20}$ The mice were fasted for $24 \mathrm{~h}$ but were allowed access to clean water ad libitum. Group 1, which received $20 \mathrm{ml} / \mathrm{kg}$ of normal saline and served as control. Groups 2, 3 and 4 were given 100,200 and $400 \mathrm{mg} / \mathrm{kg}$ respectively of the A. senegalensis extract. Group 5 was given Morphine 10 $\mathrm{mg} / \mathrm{kg}$ (standard drug). All were administered orally. Thirty min later, each mouse was restrained in a horizontal cylinder with the tail hanging freely in a water 
bath set at $52 \pm 1^{\circ} \mathrm{C}$ and the time it takes for each mouse to withdraw its tail out of the water was recorded. The latency was evaluated at 30, 60, 90 and $120 \mathrm{~min}$. The initial reading was taken immediately before administration test agents.

\section{Anti-inflammatory study}

\section{Xylene-induced ear oedema test in mice}

Adult male and female mice were divided into five groups of 6 mice in each cage were used in this study following the method as reported by Jumping et al Group1 served as control and was administered with distilled water $(20 \mathrm{ml} / \mathrm{kg}){ }^{21}$ A. senegalensis leaf extract $(100,200$ and $400 \mathrm{mg} / \mathrm{kg}$, p. o) was given to groups 2,3 and 4 respectively, while the standard drug, dexamethasone $(4 \mathrm{mg} / \mathrm{kg})$, was administered to group 5 . One-hour post drug administration, oedema was induced in each mouse by applying a drop of xylene at the inner surface of the right ear. Three hours afterwards, the animals were sacrificed under light anaesthesia and both ears were cut off to equal size and weighed. Inflammation was taken as mean difference between the right and left ear for each group.

\section{Egg albumin- induced paw oedema in rats}

Adult Wistar rats of both male and female employed in this study were randomized into five groups of 6 rats per cage. The control group (group 1) received normal saline $20 \mathrm{ml} / \mathrm{kg}$, while the extract groups (2-4) were given 100 $\mathrm{mg} / \mathrm{kg}, 200 \mathrm{mg} / \mathrm{kg}$ and $400 \mathrm{mg} / \mathrm{kg}$ of A. senegalensis respectively. The standard drug aspirin $150 \mathrm{mg} / \mathrm{kg}$ was given to group 5. All administrations were through oral cannulation. An hour after, oedema was induced in rats by injection of $0.1 \mathrm{ml}$ of fresh egg- albumin into the sub plantar of the right hind paw Essien et al The paw volumes were measured at $0,20,40,60,80,100$ and 120 min, respectively by using plethysmometer. ${ }^{22}$

\section{Antipyretic screening}

\section{Brewer's yeast-induced pyrexia}

The method described by Akuodor et al was adopted in this study with slight modification. Rats recruited for this experiment were divided into five groups of 6 rats each with their basal temperature measured using digital thermometer. The animal was subcutaneously injected with $20 \mathrm{ml} / \mathrm{kg}$ of $15 \%$ yeast suspended in $0.5 \%$ methylcellulose solution to induce pyrexia. Twenty-four hours after yeast injection, the rectal temperature of each rat was again measured and rats showing an increase of $0.6{ }^{0} \mathrm{C}$ were employed for the study. Thereafter, normal saline $20 \mathrm{ml} / \mathrm{kg}$ was administered to rats in group 1 (control), while graded doses of $A$. senegalensis ethanol leaf extract 100,200 and $400 \mathrm{mg} / \mathrm{kg}$ were orally administered to rats in groups 2,3 , and 4 respectively. The reference drug group (5) received $20 \mathrm{ml} / \mathrm{kg}$ of paracetamol. The rectal temperature of each rat was again taken at 1-hour interval for the next 5 hours. ${ }^{23}$

\section{2, 4-Dinitrophenol (DNP) - induced pyrexia.}

Adult Wistar rats were allotted to five groups of 6 animals in each cage. Their basal rectal temperatures were initially taken and $10 \mathrm{mg} / \mathrm{kg}$ of DNP was intraperitoneally injected into the rats. Hyperthermia developed 30 minutes after DNP administration. Group 1 control rats received $20 \mathrm{ml} / \mathrm{kg}$ of normal saline. The leaf extract at doses of 100, 200 and $400 \mathrm{mg} / \mathrm{kg}$ were administered to the rats in groups 2, 3 and 4 respectively, while group 5 received Paracetamol $20 \mathrm{mg} / \mathrm{kg}$. All were given by oral route. Rectal temperature of each rat was taken at an hour interval for 5 hrs. ${ }^{24,25}$

\section{Statistical analysis}

Results were expressed as means \pm SEM and analyzed with statistical package for social sciences (SPSS version 20) by using one-way analysis of variance (ANOVA) followed by Dunnett's post hoc test. Difference in the mean $\mathrm{p}<0.05$ was statistically considered significant.

\section{RESULTS}

\section{Phytochemical analysis}

It is important to know the chemical nature of plant products when their pharmacological responses are evaluated. Phytochemical evaluation of A senegalensis ethanol leaf extract showed the presence of these secondary metabolites; alkaloids, saponins, tannins, flavonoids, terpenoids, and anthraquinone, while phlobatannins and steroids were not detected. These constituents have been reported to possess important biological activities. ${ }^{26}$

Table 1: The effect of ethanol leaf extract of $A$. senegalensis on acetic acid- induced writhing in mice.

\begin{tabular}{|llll|}
\hline Drug & Dose $(\mathrm{mg} / \mathrm{kg})$ & Writhes & \% inhibition \\
\hline Control & 20 & $19.00 \pm 1.26$ & - \\
\hline \multirow{3}{*}{ A. senegalensis } & 100 & $12.67 \pm 1.4$ & 33 \\
& 200 & $5.83 \pm 0.87$ & $67^{*}$ \\
\hline Aspirin & 400 & $3.50 \pm 1.23$ & $83^{*}$ \\
\hline
\end{tabular}

Results are mean \pm SEM; $(n=6) *$ significant at $\mathrm{p}<0.05$ when compared to control 
Table 2: The effect of the ethanol leaf extract of $A$. senegalensis on tail immersion in mice time Interval (mins).

\begin{tabular}{|lllllll|} 
Drug & $\begin{array}{l}\text { Dose } \\
(\mathrm{mg} / \mathrm{kg})\end{array}$ & $\mathbf{0}$ & $\mathbf{3 0}$ & 60 & 90 & 120 \\
\hline Control & 20 & $7.17 \pm 0.87$ & $8.17 \pm 0.04$ & $9.67 \pm 1.65$ & $9.83 \pm 1.62$ & $11.67 \pm 071$ \\
\hline \multirow{2}{*}{ A. senegalensis } & 100 & $7.67 \pm 0.49$ & $10.00 \pm 0.45$ & $12.33 \pm 1.17$ & $13.17 \pm 1.10$ & $15.00 \pm 0.86 *$ \\
& 200 & $8.17 \pm 0.06$ & $12.67 \pm 1.09$ & $13.5 \pm 0.72$ & $15.17 \pm 1.30$ & $16.83 \pm 1.05 *$ \\
\cline { 2 - 7 } & 400 & $8.49 \pm 0.87$ & $14.34 \pm 0.23$ & $16.90 \pm 0.36$ & $18.05 \pm 0.74$ & $20.95 \pm 0.37 *$ \\
\hline Morphine & 10 & $8.67 \pm 1.05$ & $17.67 \pm 1.33$ & $19.67 \pm 1.70$ & $20.67 \pm 1.26$ & $23.67 \pm 1.09 *$ \\
\hline
\end{tabular}

Results are mean \pm SEM; $(n=6) *$ significant at $\mathrm{p}<0.05$ when compared to control

\section{Acute toxicity tests}

There were no lethality or toxic reactions observed at any of the doses administered. All the rats were healthy and active during and after the period of study. Hence, oral acute toxicity result was greater than $5000 \mathrm{mg} / \mathrm{kg}$ in rats.

\section{Analgesic effects}

Acetic acid induced writhing in mice

A. senegalensis leaf extract showed significant $(\mathrm{p}<0.05)$ dose dependent reduction of abdominal contraction in mice. The effect of the herbal extract at $400 \mathrm{mg} / \mathrm{kg}$ was comparable to standard drug, aspirin (Table 1).

\section{Tail immersion test in mice}

The leaf extract of A. Senegalensis significantly $(\mathrm{p}<0.05)$ protected the animals from thermal stimulus. However, the standard drug, morphine, produced a greater percentage of protection than the extract (Table 2).

\section{Anti-inflammatory effect}

Xylene - induced ear oedema in mice

The extract exerted significantly $(\mathrm{p}<0.05)$ dose dependent anti- inflammatory activity in xylene- induced ear oedema in mice. The extract compared favourably with the standard drug, Dexamethasone $4 \mathrm{mg} / \mathrm{kg}$ (Table 3).
Egg albumin - induced paw oedema in rats

The ethanol leaf extract of $A$. senegalensis exhibited significant $(\mathrm{p}<0.05)$ dose dependent anti-inflammatory activity in egg- albumin- induced paw oedema when compared to control. The effect of the extract was comparable to aspirin, the standard drug (Table 4).

\section{Antipyretic effect}

Yeast-induced pyrexia in rats.

Treatment of the animals with the ethanol extract of $A$. senegalensis, at the dose of $100 \mathrm{mg} / \mathrm{kg}, 200 \mathrm{mg} / \mathrm{kg}$ and $400 \mathrm{mg} / \mathrm{kg}$ body weight, significantly $(\mathrm{p}<0.05)$ decreased the rectal temperature of the test rats in dose dependent manner. The antipyretic effect started from the first 30 min and was maintained for $120 \mathrm{~min}$ after extract administration. The result obtained from both the standard drug and the extract - treated rats were statistically compared with control group and a significant reduction in temperature was observed (Table 5).

\section{Dinitrophenol - induced pyrexia in rats}

Administration of different doses A. senegalensis leaf extract caused a significant $(\mathrm{p}<0.05)$ reduction in temperature of the herbal treated rats when compared with the control. The antipyretic effect of the extract was comparable to that of the standard drug, aspirin (Table 6)

Table 3: The effect of ethanol leaf extract of $A$. senegalensis on xylene-induced ear oedema in mice

\begin{tabular}{|lllllll|} 
Drug & Dose $(\mathrm{mg} / \mathrm{kg})$ & Weight of right ear & $\begin{array}{l}\text { Weight of left } \\
\text { ear }\end{array}$ & $\begin{array}{l}\text { Increase in } \\
\text { ear weight }\end{array}$ & $\%$ inhibition \\
\hline Control & 20 & $0.073 \pm 0.01$ & $0.031 \pm 0.00$ & $0.042 \pm 0.00$ & - \\
\hline \multirow{3}{*}{ A. senegalensis } & 100 & $0.050 \pm 0.00$ & $0.029 \pm 0.00$ & $0.20 \pm 0.00$ & $50^{*}$ \\
\cline { 2 - 7 } & 200 & $0.038 \pm 0.00$ & $0.025 \pm 0.00$ & $0.013 \pm 0.00$ & $70^{*}$ & $78^{*}$ \\
\hline Dexamethasone & 4 & $0.032 \pm 0.01$ & $0.021 \pm 0.00$ & $0.010 \pm 0.00$ & $0.009 \pm 0.00$ & $80^{*}$ \\
\hline
\end{tabular}

Results are mean \pm SEM; $(n=6) *$ significant at $\mathrm{p}<0.05$ when compared to control. 
Table 4: The effect of ethanol leaf extract of A. senegalensis on Egg-albumin-induced paws oedema in mice.

\begin{tabular}{lllllllll|} 
Drug & $\begin{array}{l}\text { Dose } \\
(\mathrm{mg} / \mathrm{kg})\end{array}$ & $\mathbf{0}$ & $\mathbf{2 0}$ & $\mathbf{4 0}$ & $\mathbf{6 0}$ & $\mathbf{8 0}$ & $\mathbf{1 0 0}$ & 120 \\
\hline Control & 20 & $1.24 \pm 0.02$ & $1.64 \pm 0.01$ & $1.72 \pm 0.02$ & $1.79 \pm 0.02$ & $1.86 \pm 0.02$ & $1.93 \pm 0.02$ & $2.05 \pm 0.02$ \\
\hline \multirow{2}{*}{ A. } & 100 & $1.22 \pm 0.04$ & $1.60 \pm 0.02$ & $1.53 \pm 0.03$ & $1.46 \pm 0.02$ & $138 \pm 0.03$ & $1.31 \pm 0.02$ & $1.20 \pm 0.03^{*}$ \\
senegalensis & 200 & $1.24 \pm 0.02$ & $1.63 \pm 0.01$ & $1.56 \pm 0.02$ & $1.48 \pm 0.02$ & $1.30 \pm 0.02$ & $1.24 \pm 0.02$ & $18 \pm 0.02^{*}$ \\
\cline { 2 - 8 } & 400 & $1.19 \pm 0.02$ & $1.57 \pm 0.03$ & $1.49 \pm 0.03$ & $1.38 \pm 0.02$ & $1.30 \pm 0.02$ & $1.21 \pm 0.03$ & $1.15 \pm 0.03^{*}$ \\
\hline Aspirin & 150 & $1.17 \pm 0.04$ & $1.61 \pm 0.02$ & $1.49 \pm 0.02$ & $1.39 \pm 0.03$ & $1.30 \pm 0.03$ & $1.22 \pm 0.03$ & $1.12 \pm 0.03^{*}$ \\
\hline
\end{tabular}

Results are mean \pm SEM; $(n=6)$ *significantly at $\mathrm{p}<0.05$ when compared to control.

Table 5: The effect of ethanol leaf extract of $A$. senegalensis on yeast-induced pyrexia in rat time interval (hr).

\begin{tabular}{|c|c|c|c|c|c|c|c|c|}
\hline Drug & $\begin{array}{l}\text { Dose } \\
(\mathrm{mg} / \mathrm{kg})\end{array}$ & 0 & 0.5 & 1 & 2 & 3 & 4 & 5 \\
\hline Cor & 20 & $36.59 \pm 0.12$ & $37.57 \pm 0.14$ & $37.68 \pm 0.13$ & $37.76 \pm 0.12$ & $37.82 \pm 0.11$ & $38.13 \pm 0.08$ & $36.13 \pm 0.00$ \\
\hline \multirow{3}{*}{$\begin{array}{l}\text { A. } \\
\text { senegalensis }\end{array}$} & 100 & $35.63 \pm 0.17$ & $37.42 \pm 0.12$ & $37.14 \pm 0.04$ & $36.18 \pm 0.06$ & $36.71 \pm 0.08$ & $36.39 \pm 0.08$ & $35.72 \pm 0.06^{*}$ \\
\hline & 200 & $35.46 \pm 0.19$ & $37.38 \pm 0.08$ & $36.76 \pm 0.08$ & $36.57 \pm 0.09$ & $36.28 \pm 0.13$ & $35.84 \pm 0.16$ & $35.24 \pm 0.17 *$ \\
\hline & 400 & $35.50 \pm 0.13$ & $37.46 \pm 0.13$ & $36.73 \pm 0.09$ & $36.32 \pm 0.09$ & $35.99 \pm 0.09$ & $35.64 \pm 0.07$ & $35.35 \pm 0.05 *$ \\
\hline Aspirin & 150 & $36.67 \pm 0.04$ & $37.67 \pm 0.13$ & $37.38 \pm 0.06$ & $36.86 \pm 0.04$ & $36.68 \pm 0.05$ & $36.22 \pm 0.15$ & $35.10 \pm 0.30 *$ \\
\hline
\end{tabular}

Results are mean \pm SEM; $(n=6) *$ significant at $\mathrm{p}<0.05$ compared to control

Table 6: The effect of ethanol leaf extract of $A$. senegalensis on 2, 4 Dinitrophenol - induced pyrexia in rat Time interval (hr).

\begin{tabular}{|c|c|c|c|c|c|c|c|c|}
\hline Drug & $\begin{array}{l}\text { Dose } \\
(\mathrm{mg} / \mathrm{kg})\end{array}$ & 0 & 0.5 & 1 & 2 & 3 & 4 & 5 \\
\hline Cor & 20 & $35.39 \pm 0.06$ & $37.75 \pm 0.04$ & $37.88 \pm 0.03$ & $37.69 \pm 0.03$ & $37.51 \pm 0.03$ & $37.32 \pm 0.02$ & $36.72 \pm 0.02$ \\
\hline \multirow{3}{*}{$\begin{array}{l}\text { A. } \\
\text { senegalensis }\end{array}$} & 100 & $35.27 \pm 0.03$ & $37.32 \pm 0.06$ & $36.99 \pm 0.11$ & $36.45 \pm 0.03$ & $36.18 \pm 0.01$ & $35.54 \pm 0.05$ & $35.24 \pm 0.02 *$ \\
\hline & 200 & $35.29 \pm 0.03$ & $37.33 \pm 0.02$ & $36.55 \pm 0.02$ & $36.23 \pm 0.01$ & $35.68 \pm 0.04$ & $35.45 \pm 0.04$ & $35.19 \pm 0.02$ \\
\hline & 400 & $35.25 \pm 0.02$ & $37.35 \pm 0.03$ & $36.49 \pm 0.05$ & $36.24 \pm 0.04$ & $35.55 \pm 0.03$ & $35.32 \pm 0.02$ & $35.17 \pm 0.01 *$ \\
\hline paracetamol & 20 & $35.24 \pm 0.03$ & $37.25 \pm 0.03$ & $36.48 \pm 0.03$ & $36.20 \pm 0.02$ & $35.67 \pm 0.02$ & $35.41 \pm 0.02$ & $35.15 \pm 0.02 *$ \\
\hline
\end{tabular}

Results are mean \pm SEM; $(n=6) *$ significant at $\mathrm{p}<0.05$ compared to control

\section{DISCUSSION}

The present study was carried out on Anonna senegalensis leaf extract to validate its use in traditional medicine as an analgesic, anti-inflammatory and antipyretic agents. The leaf extract was found to possess analgesic activity when assessed using abdominal constriction and tail immersion tests. The response which was concentration dependent show the involvement of peripheral and central analgesic mechanisms. More so, the obtained results also indicated that $A$. senegalensis is effective in inhibiting the analgesic activity caused by the chemical stimulus in the tail immersion method. The acetic acid abdominal constriction test which is highly sensitive to the point that it is able to detect the pain relieving effect of agents and dose levels that may not be active in tail immersion method is however, believed to involve the stimulation of peripheral receptor system and is linked in part to the local peritoneal receptors on the surface of the cells lining the peritoneal cavity. ${ }^{27,28}$ The abdominal constriction test is normally used to assay the peripheral analgesic effects of medicinal agents. ${ }^{20,29}$ The observed abdominal constrictions in this study are probably due to irritation of the peritoneal cavity induced by administration of acetic acid. ${ }^{30}$ Prolonged irritation leads to an increase in the concentration of peritoneal prostaglandins PGE2 and PGF2x. ${ }^{31}$ This increase in prostaglandin levels within the peritoneal cavity then causes inflammatory pain by increasing capillary permeability. ${ }^{32}$ Furthermore, $A$. senegalensis ethanol leaf extract reasonably reduced the duration of writing in each mouse which result to the effect on arachidonate release and metabolism. ${ }^{33}$ The analgesic activity of the extract which was dose dependent may indicate the involvement of peripheral pathway. 
To further confirm the analgesic effect of the A. senegalensis extract, tail immersion test was carried out. It has been reported that centrally acting agents like morphine, elevate the pain threshold of mice towards heat and pressure, whereas peripherally acting drugs like aspirin, have been reported to possess analgesic effect in writhing activity only. ${ }^{34,35}$ The leaf extract of A. senegalensis significantly protected the animals from the thermal stimuli which confirmed its analgesic effect. This goes further to suggest a central mechanism of action of the leaf extract.

Xylene is known to cause irritation in mouse ear which leads to accumulation of fluid and oedema, characteristic of acute inflammatory response. Suppression of this response may indicate antiphlogistic effect. ${ }^{20}$ The leaf extract of $A$. senegalensis exhibited a significant inhibition of ear oedema caused by xylene. This activity suggests the inhibition of phospholipase A2 which is involved in the pathophysiology of inflammation due to xylene. ${ }^{36}$

A. senegalensis leaf extract also caused significant inhibition of Egg- albumin induced hind paw oedema in rats. Albumin-induced oedema has a biphasic response and the early phase is mediated through the release of histamine, serotonin and kinins. The late phase is related to the release of prostaglandins which is mediated by bradykinin, leucotrienes and polymorphonuclear produced by tissue macrophages. ${ }^{21,37}$ These results indicate that the extract acts on both early and late phases of inflammation. The mechanism of anti-inflammatory activity of A. senegalensis could be speculated to be through the inhibition of one or more of the released inflammatory mediators.

The leaf extract of A. senegalensis also possesses antipyretic activity. This effect was assessed using brewer's yeast and 2, 4 dinitrophenol induced pyrexia tests. It is already established that pyretic activity involves stimulation of the region in the hypothalamus that controls body temperature through prostaglandins synthesized within the central nervous system, and the blood- brain barrier prevents drug molecules or other chemicals from entering the central nervous system. 38 The regulation of body temperature requires a delicate balance between production and loss of heat, and the hypothalamus regulates the set point at which body temperature is maintained. ${ }^{39}$ The ability to cross the blood brain barrier may be one of the factors contributing to the observed antipyretic activity of $A$. senegalensis leaf extract.

The importance of medicinal plants is mostly a linked to the combination of the secondary metabolites. Different isolated flavonoids from medicinal plants have shown to possess remarkable analgesic, anti-inflammatory and antipyretic activities. ${ }^{40}$ It is not surprising however to have observed these activities in A. senegalensis leaf extract, since it contains flavonoids.

\section{CONCLUSION}

The results of this study show that the ethanol leaf extract of A. senegalenses possesses both peripheral and central analgesic activity, anti-inflammatory and antipyretic effects which thus supports the folklore uses of the leaf extract for the treatment of various diseases.

Funding: No funding sources

Conflict of interest: None declared

Ethical approval: The study was approved by the Institutional Ethics Committee

\section{REFERENCES}

1. Sharma GN, Dubey SK, Sharma P, Sati N. Medicinal value of bael (Aegle marmelos) (L.) Corr.: A review. Intern J Curr Pharm Rev Res. 2011;2(1):12-2.

2. Malwal M, Sarin R. Antimicrobial Efficacy of Murray koenigii (Linn) Spreng Root Extracts. Ind J Natio Prod Resours. 2011;2(1):48-51.

3. Kumar MM, Gopi R, Panneerselvam R. Screening of antioxidant potential of the medicinal plant Bacopa monnieri (L.) Pennell. Asia Pacif J Reprodu. 2013;2(4):253-74.

4. Ogbodoyi EO, Abdulganiy AO, Adama TZ, Okogun JI. In vivo trypanocidal activity of Annona senegalensis pers. Leaf extract against Trypanosoma brucei bruchei. J Ethnopharmacol. 2007;112:85-9.

5. Suleiman MN, Dzenda T, Sani CA. Antidiarrheal activity of the methanol stem-bark extract of Annona senegalesis pers (Annonaceae). J Ethnopharmacol. 2008; 116:125-30.

6. National Research Council. Plant Name Details for Annona Senegalensis in synopsis, Plantarum, 2008;2(1):95.1806.

7. Adzu B, Abubaka MS, Izebe KS, Akumka DD, Gamaniel KS. Effect of Annona Senegalensis root bark extracts on Naja ingricotlis Venom in rats. J. Ethnopharmacol. 2005;96:507-13.

8. Ekpendu TOE, Obande OD, Anyogo PO, Altah AD. Nigerian ethnomedicine and medicinal plants flora the Benue experience part 1. J pharm Res Dev. 1998; 6:37-46.

9. Muanza DN, Kim BW, Euler KL, William L. Antibacterial and antifungal activities of nine medicinal plants from Zaire. Int $\mathrm{J}$ Pharmacog. 1994;32:337-45.

10. Sowemimo AA, Fakoya FA, Awopetu I, Omobuwajo OR, Adesaya SA. Toxicity and mutagenic activity of some Selected Nigerian plants. J. Ethnopharmacol. 2007;113:427-32.

11. Ezugwu CO, Odoh UE. Anticonvulsant activity of the root extract of Annona senegalensis. J Trop Med Plants. 2003;4(1):51-5. 
12. More G, Tshikalang E, Lall N, Botha F, Meyer JJM. Antimicrobial activity of medicinal plants against oral microorganisms. J Ethnopharmacol. 2008;119 (3):473-7.

13. Okoli CO, Onyeto CA, Akpan BP, Ezike AC, Akah PA, Okoye TC. Neuropharmacological evaluation of Annona senegalensis leaves. Afr $\mathrm{J}$ Biotech. 2010;9(49):8435-44.

14. Nwonuma CO, Irokanulo EO, Jolaiya AE, Ore A. Effect of Aqueous Leaf Extract of Annona senegalensis on Selected Testicular Function Indices of Wistar Rats. Amer J of Life Sci. 2015;3(3):203-12.

15. NIH. Guide for the Care and Use of Laboratory Animals. 8th ed. Bethesda MD: National Institutes of Health 2011;82-3.

16. OECD (Organization for Economic Co-operation and Development). OECD Guidelines for the Testing of Chemicals / Section 4: Health Effects Test No.423: Paris: OECD 2002; Acute Oral Toxicity - Acute Toxic Class Method.

17. Aziz MA. Qualitative phytochemical screening and evaluation of anti-inflammatory, analgesic and antipyretic activities of Microcos paniculata barks and fruits. J Integra Med. 2015;13(3):173-84.

18. Evans WC. Trease and Evans Pharmacology, 15th ed. Reed Elsevier India pvt., New Delhi, India, 2005; 174:224-535.

19. Akuodor GC, Anyalewechi NA, Udoh FV, Ikoro NC, Akpan JL, Gwotmut MD, Pharmacological evaluation of verbena hastate leaf extract in the relief of fever. Adv. pharmacol. Toxicol. 2011;12(3):1-8.

20. Akuodor GC, Essien AD, Udia PM, David-Oku E, Chilaka KC, Asika EC, Nwadum SK. Analgesic, Anti-inflammatory and Antipyretic potential of the stem Bark Extract of Stachytarpheta indica. Br J Pharmacol Toxicol. 2015;6(1):16-21.

21. Jumping K, Yun N, Wang N, Liang L, Zhi - Hong H. Analgesic and anti-inflammatory activities of total extract and individual functions of Chinese medicinal plant polyrrchasis lamellidens. Bio Pharm Bull. 2005;28:176-80.

22. Essien AD, Edidara Thomas, Essiet GA, Akuodor GC. Anti-inflammatory, antipyretic and antinociceptive activities of the ethanol stem bark extract of Salacia lehmbachii. Br J Pharmacol Toxicol. 2017;8(2):9-16.

23. Akuodor GC, Essien AD, Essiet GA, Essien DO, Akpan JL, Udoh FV. Evaluation of antipyretic potential of pseudocedrela kotschyi Schweint, Harms (Meliaceae). Eur J Med Plants. 2013;3(1):105-11.

24. Okokon JE, Nwafor PA. Anti-inflammatory, analgesic and antipyretic activities of ethanolic root extract of croton zambesicus. Pak J Pharm Sci. 2010;23(4):385-92.

25. Mbagwu HOC, Anene RA, Adeyemi OO. Analgesic, antipyretic and anti-inflammatory properties of Mezoneuron benthamianum Baill Caesal pinraceae. Nigeria Quarterly J Hosp. Med. 2007;17(1):35-41.
26. Pandar S, Kar A. Anonna sqamosa seed extract in the regulation of hyperthyroidism and lipid-peroxidation in mice: Possible involvement of quercetin. Phytomed. 2007;14:799-805.

27. Zakari ZA, Abdul ZD. Antinociceptive, antiinflammatory and antipyretic properties of an aqueous extract of Dicranopteris imearis leaves in experimental animal models. J Nature Med. 2008;62: 179-87.

28. Mota MA, Landim JS, Targino TS, Silva SF, Pereiva MR. Evaluation of the anti-inflammatory and analgesic effects of green tea (Camellia sinensis) in mice. Acta Cir Bras. 2015;30(4):242-6.

29. Chang HY, Sheu MJ, Yang CH, Lu TC, Chang YS, Peng WH, et al. Analgesic effects and the mechanisms of anti-inflammation of hispolon in mice. Evid Based Complemet Altern Med. 2011;1-8.

30. Vogel HG, Vogel WH. Drug discovery and evaluation: Pharmacological assays. J. A. Majors Company. Lewisville. 1997;360-418.

31. Tarkang PA, Okalebo FA, Siminyu JD, Ngugi WN, Mwaura AM, Mugweru J, Pharmacological evidence for the folk use of Nefang: antipyretic, antiinflammatory and antinociceptic activities of its constituents. BMC Altern. Med. 2015;15:174.

32. Gawade SP. Acetic acid induced painful endogenous infliction in writhing test on mice. J Pharmacol Pharmacother, 2012;3:348.

33. Nuhu AM, Ilyas N, Ibrahim H. (2007). Analgesic and ant-inflammatory activities of aqueoue extract of Microtrichia perotitii (Astraceae). Nig J Pharm Sci. 2007;6(2):82-5.

34. Akindele AJ, Adeyemi OO. Analgesic activity of the aqueous leaf extracts of Byrsocarpus coccineus. Nigerian Journal of Health Biomed Sc. 2006;5(1):3191-6.

35. Amanlou M, Dadkhah F Salehnia A, Farsam H, Dehpour AR. Anti-inflammatory and antinorciceptive effects of hydrochloric extract of Satureja khuzistanica Jamzad extract. Journal Pharm Pharmaceut Sci. 2005;8:102-6.

36. Lin LL, Lin AY, Knopt JL. Cytosolic phospholipase A2 is coupled to hormonally regulated release of arachionic acid. Proc Natl Acid Sci. 1992;89: 6147-517.

37. Necas J, Bartosikova L. Carrageenan: A review. Vet Med (Praha). 2013;58:187-205.

38. Kumar A, Agarwal K, Kumar-Maurya A, Shanker K, Bushra U, Tandon S, Bawankule DU Pharma cological and phytochemical evaluation of Ocimum sanctum root extract for its anti-inflammatory, analgesic and antipyretic activities. Pharmacogn Mag. 2015;11(42):217-24.

39. David-Oku E, Akuodor GC, Edet EE, Ogbuji GK, Obiajunwa-Otteh JI, Aja DOJ. Antinociceptive, antiinflammatory and antipyretic effects of ethanolic root bark extract of Icacina senegalensis in rodents. J Appl Pharmaceut Sci. 2016;6(02):104-3. 
40. Essien AD, Essiet GA, Akuodor GC, Akpan JL, Chilaka KC, Bassey AL, et al. Pharmacological evaluation of the aqueous stem bark extract of Bombax buonopozense in the relief of pain and fever. Afr J Pharm Pharmaco. 2016;10(5):59-65.
Cite this article as: Megwas AU, Akuodor GC, Chukwu LC, Aja DO, Okorie EM, Ogbuagu EC, et al. Analgesic, anti- inflammatory and antipyretic activities of ethanol extract of Annona senegalensis leaves in experimental animal models. Int J Basic Clin Pharmacol. 2020;9:1477-84. 